The Umbrella Movement 


\title{
The Umbrella Movement
}

Civil Resistance and Contentious Space in Hong Kong

\author{
Edited by \\ Ngok Ma and Edmund W. Cheng
}




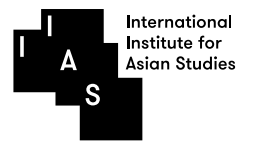

\section{Publications}

The International Institute for Asian Studies (IIAS) is a research and exchange platform based in Leiden, the Netherlands. Its objective is to encourage the interdisciplinary and comparative study of Asia and to promote (inter)national cooperation. IIAS focuses on the humanities and social sciences and on their interaction with other sciences. It stimulates scholarship on Asia and is instrumental in forging research networks among Asia Scholars. Its main research interests are reflected in the three book series published with Amsterdam University Press: Global Asia, Asian Heritages and Asian Cities.

IIAS acts as an international mediator, bringing together various parties in Asia and other parts of the world. The Institute works as a clearinghouse of knowledge and information. This entails activities such as providing information services, the construction and support of international networks and cooperative projects, and the organization of seminars and conferences. In this way, IIAS functions as a window on Europe for non-European scholars and contributes to the cultural rapprochement between Europe and Asia.

IIAS Publications Officer: Paul van der Velde

IIAS Assistant Publications Officer: Mary Lynn van Dijk

\section{Global Asia}

Asia has a long history of transnational linkage with other parts of the world. Yet the contribution of Asian knowledge, values, and practices in the making of the modern world has largely been overlooked until recent years. The rise of Asia is often viewed as a challenge to the existing world order. Such a bifurcated view overlooks the fact that the global order has been shaped by Asian experiences as much as the global formation has shaped Asia. The Global Asia Series takes this understanding as the point of departure. It addresses contemporary issues related to transnational interactions within the Asian region, as well as Asia's projection into the world through the movement of goods, people, ideas, knowledge, ideologies, and so forth. The series aims to publish timely and well-researched books that will have the cumulative efffect of developing new perspectives and theories about global Asia.

Series Editor: Tak-Wing Ngo, Professor of Political Science, University of Macau, China

Editorial Board: Kevin Hewison, Sir Walter Murdoch Distinguished Professor of Politics and International Studies, Murdoch University, Australia / Hagen Koo, Professor of Sociology, University of Hawaii, USA / Loraine Kennedy, Directrice de recherche, Centre d'Études de l'Inde et de l'Asie du Sud, École des Hautes Études en Sciences Sociales, France / Guobin Yang, Associate Professor, Annenberg School for Communication, University of Pennsylvania, USA 


\section{Publications / Global Asia}

Matthias Maass (ed.): Foreign Policies and Diplomacies in Asia. Changes in Practice, Concepts, and Thinking in a Rising Region 2014, ISBN 9789089645401

Volker Gottowik (ed.): Dynamics of Religion in Southeast Asia. Magic and Modernity 2014, ISBN 9789089644244

Frédéric Bourdier, Maxime Boutry, Jacques Ivanoff, and Olivier Ferrari: From Padi States to Commercial States. Reflections on Identity and the Social Construction of Space in the Borderlands of Cambodia, Vietnam, Thailand and Myanmar 2015, ISBN 978908964659 o

Michiel Baas (ed.): Transnational Migration and Asia. The Question of Return 2015, ISBN $97890896465^{8} 3$

Kees van Dijk: Pacific Strife. The Great Powers and Their Political and Economic Rivalries in Asia and the Western Pacific 1870-1914 2015, ISBN 9789089644206

Juliet Pietsch and Marshall Clark (eds): Migration and Integration in Europe, Southeast Asia, and Australia. A Comparative Perspective 2015, ISBN 9789089645388

Arndt Graf and Azirah Hashim (eds): African-Asian Encounters. New Cooperations and New Dependencies 2017, ISBN 9789462984288

Wendy Smith, Hirochika Nakamaki, Louella Matsunaga, and Tamasin Ramsay (eds): Globalizing Asian Religions. Management and Marketing 2018, ISBN 9789462981447 



\section{Publications}

GLOBAL ASIA 9

Cover illustration: @ Ernie Tan

Cover design: Coördesign, Leiden

Typesetting: Crius Group, Hulshout

ISBN $\quad 9789463723343$

e-ISBN $\quad 9789048552542$ (pdf)

DOI $\quad 10.5117 / 9789463723343$

NUR $\quad 740$

(c) Ngok Ma \& Edmund W. Cheng / Amsterdam University Press B.V., Amsterdam 2020

All rights reserved. Without limiting the rights under copyright reserved above, no part of this book may be reproduced, stored in or introduced into a retrieval system, or transmitted, in any form or by any means (electronic, mechanical, photocopying, recording or otherwise) without the written permission of both the copyright owner and the author of the book.

Every effort has been made to obtain permission to use all copyrighted illustrations reproduced in this book. Nonetheless, whosoever believes to have rights to this material is advised to contact the publisher. 